\title{
LIBRARY
}

STATE PLANI'BOAR"N

$\mathrm{E}-524$

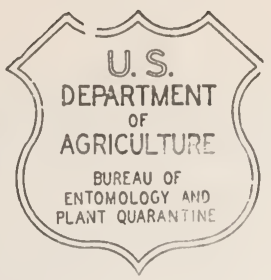

January 1941

\section{INSECT ENEMIES OF HOUSE PLANTS AND THEIR CONTROL}

By G. V. Johnson, Division of Truck Crop and Carden

Insect Investigations

Plants in houses or window boxes often become infested with various insects or other pests. Some of these pests may attack the foliage chiefly, while others may affect only the underground parts. The ones most commonly found are mealybugs, scale insects, whiteflies, aphids, red spiders, thrips, fungus gnats, and earthworms. The object of this paper is to give brief descriptions of these pests, followed by suitable control measures.

Mealybugs can be recognized by their general appearance, which is that of small objects that have been dusted with meal or flour. They are soft-bodied insects and move about very little. The eggs are placed in white cottony or fuzzy sacs, which are usually a little larger than a fullgrown mealybug. The insects and egg sacs are usually found at first on the underside of the leaves along the midrib or in the crevices where the leaves join the stem of the plant. Mealybugs obtain their food by sucking the plant juices, and, when they are abundant, the plant soon has an unthrifty appearance and growth is retarded. Mealybugs attack many plants, but they are especially troublesome on such plants as coleus, fuchsia, cactus, fern, begonia, croton, gardenia, geranium, orchid, poinsettia, citrus, ivy, ageratum, and dracaena.

A scale insect is characterized by the small shell-like covering or scale which covers its body. There are many forms, ranging from round or oval to somewhat rectangular, and one has the shape of an oystershell. In color these insects range from white to black, but browns and grays predominate. They are most often found on the stems of plants, but they may feed on the leaves and fruit as well. Their damage to the plant is similar to that of mealybugs in that they obtain their food by sucking the plant juices. Heavy infestations may not only cause retardation in growth, but also the destruction of the plant. Scale insects attack a wide variety of plants, among which are palms, rubber plants, citrus, ivy, vinca, croton, and ferns. 
Whiteflies are among the commonest insects found on ornamentals in the house, greenhouse, or window box. These small insects get their name from their appearance; their wings are snowy white, whereas their bodies may be yellowish or pinkish. When the plants are disturbed, the adults take fligit and are easily recognized while flying over and around the foliage. The younger forms of the whitefly are wingless and pale green, and they attach themselves to the under surfaces of the plant. Both the adults and the young feed, as do the mealybugs and scales, by sucking the plant juices. Infested plants lack vigor, and, when severely infested, may wilt, turn yellow, and die. The plants most commonly affected include geranium, fuchsia, ageratum, lantana, coleus, begonia, calendula, solanum, and many others.

Aphids, or plant lice, are also common pests of a very wide variety of ornamental plants. These insects are soft-bodied, usually green, although some forms, such as the nasturtium aphid, are nearly black, and others are pink, red, or brown. They usually live in colonies or clusters on the nost tender portions of the plant. Both winged and wingless plant lice may often be seen in the same cluster. Aphids feed by sucking the plant juices and, when abundant, cause severe curling and shriveling of the infested leaves and growing tips. One or more species of aphids attack nearly every species of ornamental plant.

Thrips are of several kinds. They are slender-bodied insects, yellowish to brown or black, the immature forms of which are without wings, whereas the mature forms have wings and can fly readily. They are difficult to see, however, because of their small size. The thrips differ from aphids and scales in their manner of obtaining food in that they first rupture the plant tissue with their mouth parts and then suck the plant juice. Their feeding causes a whitish spotting or "silvering" of the foliage, and the edges of the leaves wither, curl up, and die. Small black specks, which represent excretion from feeding, are usually present on the leaves of plants on which these insects have fed. Fuchsia, croton, cineraria, ageratum, and many other ornamental plants are attacked by thrips.

Red spiders (or mites) are not true insects, since they have 8 legs and insects have only 6. They obtain their name from the resemblance they bear to spiders, but are so small as to be scarcely visible to the naked eye. Red spiders vary in color, but are usually reddish or greenish. They do most of their feeding on the linder surfaces of the leaves by extracting the plant juices, but in cases of heavy infestation they feed on both surfaces of the leaves and on the stems of the plant, often covering the area over which they roam with a light web. Fed-over leaves first have a whitish appearance, later turning brownish and oftentimes dying. Most plants are subject to the attack of red spiders, but some of the smooth, hard-leaved plants, such as certain palms, are only moderately injured.

Fungus gnats are small, delicate, flylike insects. The adults are a nuisance in the house, as they fly to light and may be found, when present, swarming over the windows. The immature forms are small white maggots, and they live in the soil in pots of plants. They are particularly fond of soils containing large quantities of decaying vegetable matter. The maggots cause 
injury to the root systems by burrowing in the soil and, when abundant, they may cause actual injury by feeding on the roots and root crowns. Plants in infested pots appear unhealthy, and root rots often follow the attacks of these insects.

Earthworms often find their way into soil used in potting plants and breed very rapidly under favorable conditions. While they do not injure the plants throligh direct attack, the worms in the soil may injure the delicate root system by their continuous tunnelling.

Leaf-eating insects, such as caterpillars and other wormlike forms, beetles, and grasshoppers, which feed by biting or tearing and swallowing portions of the foliage and flowers of plants, may at times invade flower boxes and defoliate the plants. They rarely occur on plants in the home. As only a few specimens are likely to be found, these may be collected and destroyed. In case of a heavy infestation, the infested plants should be treated with a spray made by adding 3 tablespoonfuls of lead arsenate povder to a gallon of water.

\section{Control Recommendations}

Prevention.--The householder must be constantly on guard to see that plants brought into the house are not infested with insects. It is much easier to keep an insect from being introduced than to eradicate an infestation after it has become established. When plants are to be brought into the house or placed in a window box, a thorough inspection of the plants and pots should be made to see that they are not infested with any pests. Whenever repotting is necessary, be sure that insect-free soil and pots are used. Bouquets that are brought into the house should be examined to see that they do not harbor any pest which may be readily transferred to other plants.

Treatment.--The control of these pests, once they have become established on the plant, is dependent upon a timely, careful, and thorough application of the proper remedy. In some cases applications at weekly intervals may be required. Since scales, mealybugs, aphids, whiteflies, and red spiders obtain their food by sucking the plant juices, they cannot be reached with a stomach poison, such as lead arsenate, paris green, or calcium arsenate. It is necessary to apply a material to the body of the insect so as to kill by actual contact. There are many such materials on the market, the most common of which are nicotine sulfate, pyrethrum dusts and extracts, derris powder and extracts, tobacco dust, white oil emulsions, and thiocyanate sprays.

Manufacturers who sell their products interstate are required by law to label plainly all packages containing insecticides and to show the quantity of the active ingredients so the buyer can readily satisfy himself that he is obtaining the proper material. Directions for the use of commercial preparations are usually given on the containers in which they are sold. 
